ROCZNIKI TEOLOGICZNE

Tom LXVIII, zeszyt $6-2021$

DOI: https://doi.org/10.18290/rt21686-6

\title{
OCZEKIWANIA KATOLIKÓW ROZWIEDZIONYCH ŻYJĄCYCH W NOWYCH ZWIĄZKACH WOBEC DUSZPASTERSKIEGO TOWARZYSZENIA
}

\author{
EXPECTATIONS OF DIVORCED CATHOLICS \\ LIVING IN NEW RELATIONSHIPS \\ TOWARDS PASTORAL ACCOMPANIMENT
}

\begin{abstract}
A bstract. Pastoral accompaniment should be inspired by the love of God. It plays a particularly important role in ministering to Catholics who are divorced and living in new relationships. The article presents the expectations of divorced Catholics living in new relationships towards pastoral accompaniment, based on research conducted in Poland. It also contains pastoral conclusions. Respondents expect pastoral accompaniment to understand their situation, personal reasons and reasons for living in a new relationship, to discern the possibility of receiving absolution and Holy Communion, to organize retreats, to help them open up to God's love, and to support them in forgiving themselves and others. The answer to these expectations should be a parish ministry that allows for personal communication, gentle and respectful treatment and gradual integration into the life of the parish. This approach can inspire hope, trust and openness towards the Church. Reception, accompaniment and spiritual discernment enables gradual integration into the community of the Church.
\end{abstract}

Keywords: pastoral accompaniment; discernment; divorced Catholics; irregular situations.

Zaistniały w świecie kryzys społeczny i duchowy stawia przed Kościołem konieczność zrewidowania dotychczasowych sposobów realizacji zbawczego posłannictwa. Złożoność sytuacji, w jakiej dokonuje się współczesny przekaz wiary, domaga się refleksji na temat ewangelizacji. Szczególnie ważne wydaje się dowartościowanie rodziny, która jest życiodajną komórką społeczeństwa, wspólnoty kościelnej oraz naturalnym środowiskiem wychowania do wiary.

S. mgr lic. ElŻBIETA KuCZMARSKA - Doktorantka Specjalności Duszpasterstwo Rodzin (rok III), Instytut Nauk Teologicznych, Katolicki Uniwersytet Lubelski Jana Pawła II; adres do korespondencji: ul. Słowackiego 5, 25-365 Kielce; e-mail: jmjmartyna@gmail.com. ORCID: https://orcid.org/00000001-7811-5906. 
Kryzys dotykający małżeństwa i rodziny nie pozostaje w Kościele bez echa. Wśród trudnych sytuacji małżeńskich zwracają uwagę problemy dotyczące osób rozwiedzionych żyjących w nowych związkach . Papież Franciszek, świadom, że dobro rodziny ma decydujący wpływ na przyszłość świata i Kościoła, wzywa do odważnego wyjścia misyjnego i opatrywania ran 2. Kościół rozumie trudne sytuacje, przez które przechodzą małżeństwa i z niepokojem patrzy na wzrastającą liczbę rozwodów oraz powstające nowe związki. Wobec tego, z powodu kruchości kondycji ludzkiej i niesprzyjających uwarunkowań kulturowych, powinien on objąć osoby żyjące w sytuacjach nieprawidłowych towarzyszeniem duszpasterskim i rozeznawać z nimi działanie Boga w ich sytuacjach życiowych .

Zarówno dla teoretyków, jaki i praktyków duszpasterstwa interesujące jest pytanie, jakie są oczekiwania katolików rozwiedzionych żyjących w nowych związkach wobec osób podejmujących wobec nich posługę towarzyszenia duszpasterskiego? Pytanie to stało się inspiracją i przedmiotem tego opracowania. Odpowiedź na powyższe pytanie zostanie udzielona na podstawie badań społecznych przeprowadzonych w Polsce w listopadzie 2020 roku na próbie 124 rozwiedzionych katolików żyjących w powtórnych związkach. Narzędziem badawczym był składający się z 18 pytań kwestionariusz ankiety, skonstruowany w Katedrze Duszpasterstwa Rodzin KUL. Na strukturę opracowania składa się najpierw przedstawienie założeń teoretycznych towarzyszenia duszpasterskiego osobom rozwiedzionym żyjącym w nowych związkach, następnie prezentacja narzędzia badawczego, przebiegu badań oraz uzyskanych wyników, by w końcu zestawić adekwatne wnioski pastoralne.

\section{TOWARZYSZENIE DUSZPASTERSKIE ROZWIEDZIONYM W NOWYCH ZWIAZZKACH}

Papież Franciszek w adhortacji apostolskiej Amoris laetitia określił towarzyszenie centralnym kryterium duszpasterstwa. Wyraził także przekonanie,

\footnotetext{
${ }^{1}$ Por. Marian Michasiów, „Osoby rozwiedzione żyjące w nowych związkach w realiach polskiego Kościoła. Spostrzeżenia zainspirowane przedsynodalnym kwestionariuszem”, Teologia i Moralność (2014), 1, 15: 131-132; dostęp 2.01.2020, DOI: 10.14746/TIM.2014.15.1.9

2 Por. Franciszek, Posynodalna adhortacja apostolska „Amoris laaetitia” (Kraków: Wydawnictwo M, 2016), 291.

${ }^{3}$ Por. Barbara Kmiecik, ,Towarzyszenie duchowe małżonkom i osobom w sytuacjach nieregularnych w świetle adhortacji “Amoris laetitia'”, Family Forum (2017): 118-119, dostęp 23.12.2020; DOI: $10.25167 / \mathrm{FF} / 2017 / 107-124$ 118-119.
} 
że Kościół będzie musiał wprowadzić swoich członków do „sztuki towarzyszenia”, do zdrowej bliskości pełnej szacunku i współczucia, która może być lecząca i dać cenne wsparcie małżonkom w dojrzewaniu do pełni życia chrześcijańskiego . Adhortacja oferuje współczesnym małżeństwom i rodzinom drogę pełną wód miłosierdzia, na podobieństwo wody, która wypływała ze świątyni w wizji Ezechiela (por. Ez 47,1-9), drogę ułatwioną poprzez towarzyszenie, odpowiedzialne rozeznawanie i włączanie tego, co kruche, czyli naznaczone ludzką słabością ${ }^{5}$ Nie można też zapominać, że Bóg nie polega tylko na tym, co jest w człowieku dobre i zwycięskie. Większość Jego planów jest realizowana poprzez ludzkie słabości i pomimo nich, a prawda pochodząca od Niego nie potępia, ale akceptuje, obejmuje, wspiera i przebacza (por. Łk 15,11-32). Jest to prawda, która wychodzi na spotkanie, przywraca godność, wzmacnia i podnosi .

Pierwszym, który towarzyszy człowiekowi swoją obecnością i łaską, jest Bóg. Stanowi to źródło oraz inspirację dla duszpasterstwa eklezjalnego . Towarzyszenie duszpasterskie jest zadaniem całej wspólnoty kościelnej, a szczególnie duszpasterzy, zakonników, wyspecjalizowanych osób świeckich oraz małżonków umiejących wspierać inne osoby w rozwoju wiary i miłości ${ }^{8}$. Sposób i zakres niesionej pomocy winien być podyktowany dobrze rozeznanymi potrzebami drugiego człowieka ${ }^{9}$. Do istotnych elementów korzystania z tej posługi zalicza się stawanie w prawdzie, świadomość procesu, odwagę mierzenia się z własną kruchością. To wszystko pozwala przekraczać siebie i dojrzewać Celem towarzyszenia jest pomoc innym w stawaniu się autentycznymi budowniczymi swego życia poprzez wspieranie w budowaniu żywej relacji z Jezusem i pomoc $w$ prowadzeniu osobistego rozeznawania ${ }^{11}$. Podejmując się wspierającej

\footnotetext{
${ }^{4}$ Por. Franciszek, Amoris laaetitia, 294; por. Richard Kucharčík, „Dowartościowanie świadectwa i towarzyszenia małżonków", w Towarzyszyć matżeństwu i rodzinie. Inspiracje adhortacji apostolskiej Amoris laetitia dla duszpasterstwa rodzin, red. Jacek Goleń (Lublin: Wydawnictwo KUL, 2017), 217.

${ }^{5}$ Por. Nestor Basunga Kiama Zinga, ,Teologiczne punkty węzłowe małżeństwa chrześcijańskiego", w Amoris laetitia jako ewangelia mitości i droga do przebycia, red. Giovanni del Missier, Antonio Gerardo Fidalgo (Kraków: Wydawnictwo Homo Dei, 2019), 99-102.

${ }^{6}$ Por. Franciszek, List apostolski „Patris corde”, 2, dostęp 20.12.2020, http://www.vatican.va/ content/francesco/pl/apost_letters/documents/papa-francesco-lettera-ap_20201208_patris-corde.html.

${ }^{7}$ Por. Jacek Goleń, „Towarzyszenie, rozeznawanie i integracja osób w nieuregulowanych sytuacjach małżeńskich”, w Konrad Glombik, Jacek Goleń, Antoni Nadbrzeżny, Droga miłosierdzia $i$ integracji $w$ adhortacji 'Amoris laetitia'. Perspektywa dogmatyczna, moralna i pastoralna, (Lublin: Towarzystwo Naukowe KUL, 2020), 114.

${ }^{8}$ Por. Kucharčík, „Dowartościowanie świadectwa”, 217.

${ }^{9}$ Por. Franciszek, Adhortacja apostolska Evangelii gaudium (Kraków: Wydawnictwo M, 2013), 17; por. Kmiecik, „Towarzyszenie duchowe”, 109.

${ }^{10}$ Por. Kmiecik, ,Towarzyszenie duchowe”, 110.

${ }^{11}$ Por. Goleń, „Towarzyszenie, rozeznawanie”, 115.
} 
obecności trzeba mieć świadomość, że staje się wobec tajemnicy każdej osoby, by pomóc jej narodzić się dla prawdy własnego życia ${ }^{12}$. Domaga się to postawy pełnej pokory wobec prawdy drugiej osoby oraz umiejętności ,zdejmowania sandałów" wobec świętej ziemi drugiego (por. Wj 3,5) .

Zagadnienie towarzyszenia duchowego osobom w nieuregulowanych sytuacjach małżeńskich traktowano dotąd peryferyjnie. Propozycja towarzyszenia i rozeznawania znajduje szczególne miejsce w nauczaniu papieża Franciszka ${ }^{14}$. Kościół obecnie podejmuje próby zintensyfikowania troski o rodziny, docierając do nich z pokornym zrozumieniem oraz chęcią towarzyszenia na różnych etapach życia i w różnych sytuacjach ${ }^{15}$. Duszpasterskie towarzyszenie osobom rozwiedzionym i opuszczonym winno polegać przede wszystkim na życzliwym wysłuchaniu i dowartościowaniu cierpienia tych, którzy doświadczyli nie-

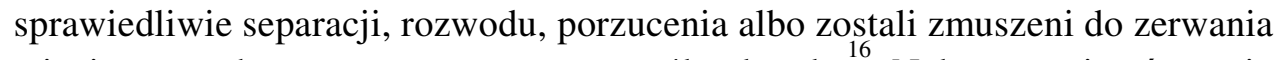
więzi z powodu przemocy ze strony współmałżonka ${ }^{16}$. Należy pamiętać, że nie występuje przeciw małżeństwu małżonek decydujący się na separację z powodu przemocy, jakiej doświadcza on sam i rodzina. Wręcz przeciwnie, taką postawą paradoksalnie zaświadcza o pięknie i świętości więzi małżeńskiej, chroniąc ją przed niesprawiedliwością i zniesławieniem ${ }^{17}$.

Papież szczególnie uwrażliwia na potrzebę towarzyszenia w życiu wiary osobom zranionym, które na skutek nieodwracalnego rozpadu więzi małżeńskiej zdecydowały się na życie w nowym związku . Historia każdego dramatu małżeńskiego jest inna i konieczne jest indywidualne spojrzenie $\mathrm{z}$ miłością na człowieka poszukującego możliwości pojednania z Bogiem i Kościołem. Zaproszenie do rozmowy, cierpliwe wysłuchanie i zrozumienie subiektywnych powodów, dla których osoba żyje w ten sposób, to pierwszy i ważny krok duszpasterskiego towarzyszenia ${ }^{19}$. Jeśli osoba pragnie nawrócenia i jest gotowa naprawić swoje błędy, warto rozważyć możliwość podjęcia drogi pojednania

\footnotetext{
${ }^{12}$ Por. Kmiecik, Towarzyszenie duchowe”, 122.

${ }^{13}$ Por. Goleń, ,Towarzyszenie, rozeznawanie”, 115.

${ }^{14}$ Por. Jacek Goleń, „The Challenges of Accompanying the Family in Light of the Apostolic Exhortation Amoris Laetitia”, Rocznik Teologii Katolickiej 17(2018), 1: 112-115.

${ }^{15}$ Por. Jacek Golen,, „The Renewal of Pastoral Care of the Family in the Light of the Apostolic Exhortation Amoris Laetitia”, Roczniki Teologiczne 64(2017), 6: 108-111.

${ }^{16}$ Por. Jan Krajczyński, „Duszpasterstwo małżonków rozwiedzionych i żyjących w nowych związkach”, w Towarzyszyć małżeństwu i rodzinie. Inspiracje adhortacji apostolskiej 'Amoris laetitia' dla duszpasterstwa rodzin, red. Jacek Goleń (Lublin: Wydawnictwo KUL, 2017), 408.

${ }^{17}$ Por. Papieska Komisja Biblijna, Czym jest cztowiek? Zarys antropologii biblijnej (Kielce: Jedność, 2019), 178.

${ }^{18}$ Por. Franciszek, Rodzina uratuje świat (Gliwice: Fundacja Instytut Globalizacji, 2016), 118.

${ }^{19}$ Por. Goleń, ,Towarzyszenie, rozeznawanie”, 129.
} 
i o ile to możliwe, powrotu do sakramentalnego współmałżonka. W sytuacjach, gdy brak takiej gotowości, bądź istnieje subiektywne przekonanie o niemożności tego kroku, warto zachęcać osoby do modlitwy i formacji chrześcijańskiej. Takie postępowanie pozwala wejść na drogę uzdrowienia duchowego, przebaczenia i pojednania oraz naprawienia ewentualnych krzywd. Okazane w ten sposób wsparcie duszpasterskie może zapoczątkować drogę pojednania z sobą, Bogiem oraz ludźmi . W przypadkach, w których powstają wątpliwości, towarzyszenie jest pomocne we wstępnym zapoznaniu się z sytuacją małżeńską. Może ono także zachęcić wiernych do zwrócenia się do sądu kościelnego celem kanonicznego zbadania ważności małżeństwa sakramentalnego i podjęcia działania weryfikującego zasadność ${ }^{21}$.

Osoby rozwiedzione, które zawarły ponowne związki, nadal przynależą do Kościoła, który ze szczególną troską winien im towarzyszyć w kultywowaniu chrześcijańskiego stylu życia. Ważne jest zachęcanie ich do modlitwy, słuchania słowa Bożego, uczestnictwa we Mszy św., adoracji eucharystycznej, czynów miłości oraz chrześcijańskiego wychowania dzieci. Pomimo niepełnego uczestnictwa w życiu Kościoła osoby rozwiedzione nadal doświadczają działania łaski Bożej pobudzającej ich do wzajemnej troski, dobrych czynów oraz służenia dobru wspólnoty kościelnej ${ }^{22}$. Jednocześnie trzeba pamiętać, że niektórzy ochrzczeni rozwiedzeni, żyjący w nowych związkach, którzy nie otrzymali stwierdzenia nieważności sakramentu, obecnie nie mogą już zmienić swojej sytuacji. Jeśli jednak dążą do nawrócenia i pragną coraz głębszego zjednoczenia z Bogiem, wówczas potrzebują pilnie duszpasterskiego towarzyszenia, a szczególnie rozeznawania aktualnej odpowiedzialności moralnej ${ }^{23}$. Życie w nowym związku może również wiązać się z trudnościami w podejściu do własnej seksualności i jej przeżywaniu - niepełnym rozumieniem więzi miłości małżeńskiej ${ }^{24}$, a także z ich oceną moralną ${ }^{25}$. Niezmiernie ważne jest

\footnotetext{
${ }^{20}$ Por. Goleń, „Towarzyszenie, rozeznawanie”, 130.

${ }^{21}$ Por. Benedykt XVI, Posynodalna adhortacja apostolska Sacramentum caritatis, 29, dostęp 28.12.2020, http://www.vatican.va/content/benedict-xvi/pl/apost_exhortations/documents/hf_ben -xvi_exh_20070222_sacramentum-caritatis.html.

${ }^{22}$ Por. Antoni Nadbrzeżny, ,Sens i wartość sakramentu małżeństwa według adhortacji 'Amoris laetitia”,' w Konrad Glombik, Jacek Goleń, Antonii Nadbrzeżny, Droga miłosierdzia i integracji w adhortacji 'Amoris laetitia', 60-61.

${ }^{23}$ Por. Jacek Goleń, „Pastoral Accompaniment for People in Irregular Situations”, w Catholic Family Ministry. The Scientific Reflection and the Practical Ministry of the Church, red. Jacek Golen, Ryszard Kamiński, Grzegorz Pyźlak (Lublin: Wydawnictwo KUL, 2018), 459-463.

${ }^{24}$ Por. Jacek Goleń, „Miłość małżeńska w świetle badań narzeczonych”, Studia nad Rodzina 18(2014), 2, 35: 131.

${ }^{25}$ Por. Franciszek, Amoris laetitia, 305, przypis 351.
} 
objęcie osób w takich sytuacjach uważnym towarzyszeniem pełnym szacunku, oraz unikanie postaw, które dałyby im odczuć, że są dyskryminowane ${ }^{26}$. Istotnym elementem tego towarzyszenia jest rozeznawanie wraz z kierownikiem duchowym lub spowiednikiem. Rozeznawanie to jest pomocne nie tylko dla odbycia rachunku sumienia i rozpoznania swojej sytuacji przed Bogiem, ale $\mathrm{w}$ poszukiwaniu Jego woli i doskonalszej na nią odpowiedzi ${ }^{27}$. Należy pamiętać, że również w związku przypominającym małżeństwo mogą istnieéc aspekty mające wartość etyczną przed Bogiem, takie jak wychowanie dzieci ${ }^{28}$. Dlatego wspólne z duszpasterzem poszukiwanie prawdy, otwarte na słowo Boże i uległość Duchowi Świętemu, pozwala rozeznawać możliwość dawania odpowiedzi Bogu w aktualnej sytuacji i służy coraz pełniejszej integracji we wspólnocie Kościoła ${ }^{29}$.

\section{BADANA GRUPA I PRZEBIEG BADAŃ}

Oczekiwania małżonków rozwiedzionych, żyjących w nowych związkach wobec duszpasterskiego towarzyszenia, weryfikowano metodą sondażową. W badaniach wykorzystano kwestionariusz ankiety, skonstruowany w Katedrze Duszpasterstwa Rodzin Katolickiego Uniwersytetu Lubelskiego Jana Pawła II. Wypowiedzi uzyskane $\mathrm{z}$ badań pilotażowych, przeprowadzonych $\mathrm{w}$ formie wywiadów z osobami rozwiedzionymi, żyjącymi w nowych związkach, stanowią treść poszczególnych pytań. Drugie źródło merytoryczne stanowią założenia normatywne odnoszące się do duszpasterskiej troski o osoby w sytuacjach nieuregulowanych, znajdujące się w nauczaniu Kościoła.

Respondenci zostali poproszeni o udzielenie odpowiedzi na 18 pytań opatrzonych pięciopunktową skalą od 0 do 4 punktów. To pozwoliło wskazać stopień akceptacji danego twierdzenia. Poszczególnym punktom na skali przyporządkowano następujące znaczenia: 0 - zdecydowanie nie oczekuję; 1 - w małym stopniu oczekuję; 2 - w średnim stopniu oczekuję; 3 - w dużym stopniu oczekuję i 4 - zdecydowanie, bardzo oczekuję. Kwestionariusz został rozesłany do wybranych par drogą internetową z wykorzystaniem narzędzia Formularze Google.

\footnotetext{
${ }^{26}$ Por. Kmiecik, Towarzyszenie duchowe", 117.

${ }^{27}$ Por. Goleń, ,Towarzyszenie, rozeznawanie”, 141-152.

${ }^{28}$ Por. Nadbrzeżny, „Sens i wartość sakramentu”, 60.

${ }^{29}$ Por. Zinga, ,Teologiczne punkty węzłowe”, 99-102.
} 
W obliczeniach statystycznych wykorzystano standardowe metody analizy opisowej i statystycznej. Uzyskane wyniki zaprezentowano jako częstość odpowiedzi (\% grupy) oraz wielkość grup udzielających odpowiedzi (n z całości grupy badanej). Ze względu na wykorzystanie skali porządkowej w zakresie oceny od 0 do 4 dla oceny wyników, wykorzystano również średnią arytmetyczną (M), medianę (Me) oraz odchylenie standardowe (SD). Do analizy wyników wykorzystano następujące testy statystyczne: test Shapiro-Wilka do oceny zgodności rozkładu do rozkładu normalnego; test Manna-Whitney'a (odpowiedni test t Studenta, do porównań 2 grup), którym analizowano zmienne nieposiadające rozkładu zbliżonego do rozkładu normalnego, wykorzystany do analizy między grupami oraz test Kruskala-Wallisa (odpowiednik testu ANOVA, do porównań 3 lub większej liczby grup). Obliczeń statystycznych dokonano za pomocą pakietu SPSS 14.0PL ${ }^{30}$.

Grupę badawczą stanowili katolicy rozwiedzeni żyjący w nowych związkach. Próba badawcza składała się z 124 osób, w tym z 92 kobiet i 32 mężczyzn. Ze względu na wiek respondentów wyróżniono osoby w wieku do 35 lat $(25,81 \%)$, osoby w przedziale wiekowym $36-55$ lat $(43,55 \%)$ oraz osoby w wieku 56 lat i więcej $(30,65 \%)$. Biorąc pod uwagę wykształcenie respondentów wyróżniono trzy grupy: pierwszą stanowiły osoby z wykształceniem podstawowym, zawodowym i średnim $(48,39 \%)$; drugą osoby z wykształceniem wyższym humanistycznym $(24,0 \%)$, a trzecią osoby z wykształceniem wyższym technicznym i wyższym w zakresie nauk ścisłych $(27,42 \%)$. Ponad połowa respondentów deklarowała się jako głęboko wierzący i praktykujący $(53,0 \%)$, a pozostali badani jako wierzący, słabo praktykujący i słabo wierzący $(46,77 \%)$. Ze względu na rodzinę pochodzenia wyodrębniono osoby wychowujące się w rodzinie pełnej $(77,0 \%)$ oraz osoby wychowujące się w rodzinie, gdzie miał miejsce rozwód, w rodzinie niepełnej czasowo lub w rodzinie stale niepełnej, z jednym rodzicem $(22,58)$. Spośród badanych małżonków 8,0\% nie miało rodzeństwa, 34,0\% posiadało jednego brata lub siostrę, a 58,06\% posiadało dwoje i więcej rodzeństwa. Badania zostały przeprowadzone w listopadzie $2020 \mathrm{r}$.

\section{PREZENTACJA WYNIKÓW BADAŃ}

W przeprowadzonych badaniach zapytano osoby rozwiedzione żyjące w nowych związkach o oczekiwania wobec duszpasterskiego towarzyszenia parom. Wyniki prezentuje tabela 1.

\footnotetext{
${ }^{30}$ SPSS 14.0PL
} 
Tabela 1. Liczbowy i procentowy rozkład odpowiedzi respondentów dotyczących oczekiwań wobec towarzyszenia duszpasterskiego parom w sytuacjach nieuregulowanych

\begin{tabular}{|c|c|c|c|c|c|c|c|c|c|}
\hline \multicolumn{2}{|l|}{$\begin{array}{l}\text { Oczekiwania wobec towarzyszenia } \\
\text { duszpasterskiego }\end{array}$} & \multirow{2}{*}{\begin{tabular}{|c|}
$\mathbf{O - 0} *$ \\
6
\end{tabular}} & \multirow{2}{*}{\begin{tabular}{r|}
$\mathbf{O - 1}$ \\
16
\end{tabular}} & \multirow{2}{*}{\begin{tabular}{|l|}
$\mathbf{O - 2}$ \\
20
\end{tabular}} & \multirow{2}{*}{\begin{tabular}{r|}
$\mathbf{O - 3}$ \\
24
\end{tabular}} & \multirow{2}{*}{\begin{tabular}{r|}
$\mathbf{O - 4}$ \\
58
\end{tabular}} & \multirow{2}{*}{\begin{tabular}{c|}
$\mathbf{M}$ \\
2,90
\end{tabular}} & \multirow{2}{*}{\begin{tabular}{l|} 
SD \\
1,26
\end{tabular}} & \multirow{2}{*}{$\begin{array}{l}\text { Me } \\
3,00\end{array}$} \\
\hline $\begin{array}{l}\text { Wyjaśnianie, w jaki sposób budować więź } \\
\text { duchową z Bogiem i partnerem }\end{array}$ & $\mathrm{N}$ & & & & & & & & \\
\hline & $\%$ & 4,8 & 12,9 & 16,1 & 19,4 & 46,8 & & & \\
\hline \multirow{2}{*}{$\begin{array}{l}\text { tworzenie wspólnot dla par } \\
\text { niesakramentalnych, gdzie moglibyśmy } \\
\text { dzielić się doświadczeniami }\end{array}$} & $\mathrm{N}$ & 14 & 16 & 14 & 16 & 64 & 2,81 & 1,47 & 4,00 \\
\hline & $\%$ & 11,3 & 12,9 & 11,3 & 12,9 & 51,6 & & & \\
\hline \multirow[t]{2}{*}{ zapraszanie nas do udziału we Mszy świętej } & $\mathrm{N}$ & 10 & 4 & 30 & 26 & 54 & 2,89 & 1,24 & 3,00 \\
\hline & $\%$ & 8,1 & 3,2 & 24,2 & 21,0 & 43,5 & & & \\
\hline \multirow[t]{2}{*}{$\begin{array}{l}\text { organizowanie rekolekcji dla par } \\
\text { w sytuacjach nieuregulowanych }\end{array}$} & $\mathrm{N}$ & 10 & 10 & 14 & 26 & 64 & 3,00 & 1,31 & 4,00 \\
\hline & $\%$ & 8,1 & 8,1 & 11,3 & 21,0 & 51,6 & & & \\
\hline \multirow[t]{2}{*}{$\begin{array}{l}\text { uwagę kapłanów i większe zainteresowanie } \\
\text { naszą sytuacją }\end{array}$} & $\mathrm{N}$ & 4 & 8 & 24 & 20 & 68 & 3,13 & 1,14 & 4,00 \\
\hline & $\%$ & 3,2 & 6,5 & 19,4 & 16,1 & 54,8 & & & \\
\hline \multirow[t]{2}{*}{ pomoc w osobistej modlitwie słowem Bożym } & $\mathrm{N}$ & 14 & 14 & 14 & 40 & 42 & 2,66 & 1,35 & 3,00 \\
\hline & $\%$ & 11,3 & 11,3 & 11,3 & 32,3 & 33,9 & & & \\
\hline \multirow{2}{*}{$\begin{array}{l}\text { zapraszanie na drogę rozeznawania ze } \\
\text { spowiednikiem możliwości otrzymania } \\
\text { rozgrzeszenia i przyjęcia Komunii świętej }\end{array}$} & $\mathrm{N}$ & 10 & 8 & 10 & 14 & 82 & 3,21 & 1,31 & 4,00 \\
\hline & $\%$ & 8,1 & 6,5 & 8,1 & 11,3 & 66,1 & & & \\
\hline \multirow[t]{2}{*}{$\begin{array}{l}\text { wyjaśnianie, co to jest komunia duchowa } \\
\text { i jak ją przyjmować }\end{array}$} & $\mathrm{N}$ & 12 & 14 & 26 & 16 & 56 & 2,73 & 1,39 & 3,00 \\
\hline & $\%$ & 9,7 & 11,3 & 21,0 & 12,9 & 45,2 & & & \\
\hline \multirow[t]{2}{*}{$\begin{array}{l}\text { pomoc duchową w przebaczaniu sobie } \\
\text { i innym oraz naprawieniu krzywd }\end{array}$} & $\mathrm{N}$ & 10 & 8 & 20 & 24 & 62 & 2,97 & 1,29 & 3,50 \\
\hline & $\%$ & 8,1 & 6,5 & 16,1 & 19,4 & 50,0 & & & \\
\hline \multirow[t]{2}{*}{$\begin{array}{l}\text { zapraszanie nas na adorację Najświętszego } \\
\text { Sakramentu }\end{array}$} & $\mathrm{N}$ & 6 & 22 & 22 & 26 & 48 & 2,71 & 1,29 & 3,00 \\
\hline & $\%$ & 4,8 & 17,7 & 17,7 & 21,0 & 38,7 & & & \\
\hline \multirow{2}{*}{$\begin{array}{l}\text { zachęcanie do zbadania w sądzie biskupim } \\
\text { ważności naszego małżeństwa } \\
\text { sakramentalnego }\end{array}$} & $\mathrm{N}$ & 24 & 16 & 18 & 20 & 46 & 2,39 & 1,56 & 3,00 \\
\hline & $\%$ & 19,4 & 12,9 & 14,5 & 16,1 & 37,1 & & & \\
\hline
\end{tabular}




\begin{tabular}{|l|c|c|c|c|c|c|c|c|c|}
\hline $\begin{array}{l}\text { pomoc w otwieraniu się na miłość Boga do } \\
\text { nas }\end{array}$ & $\mathrm{N}$ & 14 & 8 & 14 & 28 & 60 & 2,90 & 1,38 & 3,00 \\
\hline & $\%$ & 11,3 & 6,5 & 11,3 & 22,6 & 48,4 & & & \\
\hline $\begin{array}{l}\text { wsparcie w kryzysie z powodu poczucia } \\
\text { wykluczenia z Kościoła }\end{array}$ & $\mathrm{N}$ & 14 & 18 & 14 & 20 & 58 & 2,73 & 1,46 & 3,00 \\
\hline & $\%$ & 11,3 & 14,5 & 11,3 & 16,1 & 46,8 & & & \\
\hline $\begin{array}{l}\text { zrozumienie przez duszpasterzy naszej } \\
\text { sytuacji oraz osobistych racji i powodów } \\
\text { życia w nowym związku }\end{array}$ & $\mathrm{N}$ & 6 & 2 & 8 & 22 & 86 & 3,45 & 1,04 & 4,00 \\
\hline & $\%$ & 4,8 & 1,6 & 6,5 & 17,7 & 69,4 & & & \\
\hline $\begin{array}{l}\text { zapraszanie nas do czynienia możliwego } \\
\text { dobra w aktualnej sytuacji, w jakiej się } \\
\text { znajdujemy }\end{array}$ & $\mathrm{N}$ & 10 & 10 & 14 & 26 & 64 & 3,00 & 1,31 & 4,00 \\
\hline & $\%$ & 8,1 & 8,1 & 11,3 & 21,0 & 51,6 & & & \\
\hline $\begin{array}{l}\text { organizowanie modlitw o uzdrowienie } \\
\text { zranień w relacjach }\end{array}$ & $\mathrm{N}$ & 12 & 14 & 26 & 28 & 44 & 2,63 & 1,33 & 3,00 \\
\hline & $\%$ & 9,7 & 11,3 & 21,0 & 22,6 & 35,5 & & & \\
\hline pomoc w religijnym wychowaniu dzieci & $\mathrm{N}$ & 16 & 12 & 24 & 32 & 40 & 2,55 & 1,38 & 3,00 \\
\hline & $\%$ & 12,9 & 9,7 & 19,4 & 25,8 & 32,3 & & & \\
\hline $\begin{array}{l}\text { stwarzanie okazji do włączenia się w życie } \\
\text { parafii }\end{array}$ & $\mathrm{N}$ & 16 & 6 & 30 & 28 & 44 & 2,63 & 1,36 & 3,00 \\
\hline & $\%$ & 12,9 & 4,8 & 24,2 & 22,6 & 35,5 & & & \\
\hline
\end{tabular}

*Oznaczenia: M - średnia, SD - odchylenie standardowe; Me - mediana; 0 - zdecydowanie nie oczekuję; 1 - w małym stopniu oczekuję; 2 - w średnim stopniu oczekuję; 3 - w dużym stopniu oczekuję; 4 - zdecydowanie, bardzo oczekuję.

Zaprezentowane wyniki w tabeli 1. wskazują, że trzy czwarte katolików rozwiedzionych, żyjących w nowych związkach, zdecydowanie lub w dużym stopniu oczekuje od duszpasterskiego towarzyszenia zrozumienia przez duszpasterzy ich sytuacji oraz osobistych racji i powodów życia w nowym związku $(87,1 \%)$, zapraszania na drogę rozeznawania ze spowiednikiem możliwości otrzymania rozgrzeszenia i przyjęcia Komunii świętej $(77,4 \%)$, organizowania rekolekcji dla par w sytuacjach nieuregulowanych i zapraszania ich do czynienia możliwego dobra w aktualnej sytuacji, w jakiej się znajdują (72,6\%), pomocy w otwieraniu się na miłość Boga (71\%), uwagi kapłanów i większego zainteresowania ich sytuacją (70,9\%), pomocy duchowej w przebaczaniu sobie i innym oraz naprawieniu krzywd $(69,4 \%)$. Około dwie trzecie 
respondentów zdecydowanie lub w dużym stopniu oczekuje od duszpasterskiego towarzyszenia wyjaśniania, w jaki sposób budować więź duchową z Bogiem i partnerem oraz pomocy w osobistej modlitwie Słowem Bożym $(66,2 \%)$, tworzenia wspólnot dla par niesakramentalnych, gdzie byłaby możliwość dzielenia się doświadczeniami oraz zapraszania do udziału we Mszy świętej $(64,5 \%)$, wsparcia w kryzysie z powodu poczucia wykluczenia z Kościoła $(62,9 \%)$, wyjaśniania, co to jest komunia duchowa i jak ją przyjmować, organizowania modlitw o uzdrowienie zranień w relacjach, pomocy w religijnym wychowaniu dzieci i tworzenia okazji do włączenia się w życie parafii $(58,1 \%)$. Ponad połowa oczekuje równie intensywnie zachęty do zbadania w sądzie biskupim ważności małżeństwa sakramentalnego $(53,2 \%)$.

Warto zauważyć, że nie mały procent respondentów zdecydowanie nie oczekuje lub w małym stopniu oczekuje zachęty do zbadania w sądzie biskupim ważności małżeństwa sakramentalnego $(31,3 \%)$, wsparcia w kryzysie z powodu poczucia wykluczenia z Kościoła $(25,8 \%)$, tworzenia wspólnot dla par niesakramentalnych, gdzie mogliby dzielić się doświadczeniami $(24,2 \%)$, pomocy w osobistej modlitwie słowem Bożym i w religijnym wychowaniu dzieci $(22,6 \%)$, zapraszania na adorację Najświętszego Sakramentu $(22,5 \%)$, wyjaśniania, co to jest komunia duchowa i jak ją przyjmować, a także organizowania modlitw o uzdrowienie zranień w relacjach $(21,0 \%)$, pomocy w otwieraniu się na miłość Boga (17,8\%), wyjaśniania, w jaki sposób budować więź duchową z Bogiem i partnerem, stwarzania okazji do włączenia się w życie parafii $(17,7 \%)$, organizowania rekolekcji dla par w sytuacjach nieuregulowanych i zapraszania do czynienia możliwego dobra w aktualnej sytuacji, w jakiej się znajdują $(16,2 \%)$, zapraszania na drogę rozeznawania ze spowiednikiem możliwości otrzymania rozgrzeszenia i przyjęcia Komunii świętej, pomocy duchowej w przebaczaniu sobie i innym oraz naprawieniu krzywd (14,6\%); zapraszania do udziału we Mszy świętej (11,3\%). Pozostałe wyniki osiągnęły wartość poniżej 10,0\%.

$\mathrm{W}$ toku analiz uwzględniono także oddziaływanie zmiennych niezależnych na odpowiedzi respondentów dotyczące ich oczekiwań względem duszpasterskiego towarzyszenia. Zróżnicowanie wystąpiło dla zmiennej wieku. Porównania dokonano za pomocą testu Kruskala-Wallisa. Wyniki prezentuje tabela 2. 
Tabela 2. Oczekiwania wobec towarzyszenia duszpasterskiego w sytuacjach nieuregulowanych a wiek respondentów

\begin{tabular}{|c|c|c|c|c|c|c|c|c|c|}
\hline \multirow[t]{2}{*}{$\begin{array}{l}\text { Oczekiwania wobec } \\
\text { towarzyszenia } \\
\text { duszpasterskiego }\end{array}$} & \multicolumn{2}{|c|}{$\begin{array}{c}26-35 \text { lat } \\
(n=32)\end{array}$} & \multicolumn{2}{|c|}{$\begin{array}{c}\text { 36-55 lat } \\
(n=54)\end{array}$} & \multicolumn{2}{|c|}{$\begin{array}{c}56 \text { i więcej lat } \\
(n=38)\end{array}$} & \multirow[t]{2}{*}{$\mathbf{d M}$} & \multirow[t]{2}{*}{$\mathbf{H}$} & \multirow[t]{2}{*}{$\mathbf{p}$} \\
\hline & $\mathbf{M}^{*}$ & SD & $\mathbf{M}$ & SD & M & SD & & & \\
\hline Wynik sumaryczny & 63,11 & 25,58 & 70,32 & 26,91 & 79,31 & 21,69 & 16,21 & 9,749 & 0,008 \\
\hline \multicolumn{10}{|l|}{ Pytania szczegółowe } \\
\hline $\begin{array}{l}\text { tworzenie wspólnot dla } \\
\text { par niesakramentalnych, } \\
\text { gdzie moglibyśmy dzielić } \\
\text { się doświadczeniami }\end{array}$ & 2,25 & 1,41 & 2,74 & 1,52 & 3,37 & 1,24 & 1,12 & 13,249 & 0,001 \\
\hline $\begin{array}{l}\text { zapraszanie nas do } \\
\text { udziału we Mszy świętej }\end{array}$ & 2,13 & 1,13 & 3,07 & 1,20 & 3,26 & 1,13 & 1,14 & 21,106 & $<0,001$ \\
\hline $\begin{array}{l}\text { organizowanie rekolekcji } \\
\text { dla par w sytuacjach } \\
\text { nieuregulowanych }\end{array}$ & 2,38 & 1,52 & 2,93 & 1,20 & 3,63 & 0,94 & 1,26 & 19,141 & $<0,001$ \\
\hline $\begin{array}{l}\text { uwagę kapłanów } \\
\text { i większe zainteresowanie } \\
\text { naszą sytuacją }\end{array}$ & 2,63 & 1,29 & 3,11 & 1,14 & 3,58 & 0,76 & 0,95 & 12,651 & 0,002 \\
\hline $\begin{array}{l}\text { zapraszanie na drogę } \\
\text { rozeznawania ze } \\
\text { spowiednikiem } \\
\text { możliwości otrzymania } \\
\text { rozgrzeszenia i przyjęcia } \\
\text { Komunii świętej }\end{array}$ & 2,69 & 1,51 & 3,19 & 1,29 & 3,68 & 0,93 & 1,00 & 10,678 & 0,005 \\
\hline $\begin{array}{l}\text { pomoc duchową } \\
\text { w przebaczaniu sobie } \\
\text { i innym oraz naprawieniu } \\
\text { krzywd }\end{array}$ & 2,81 & 1,45 & 2,67 & 1,37 & 3,53 & 0,76 & 0,86 & 9,165 & $\mathbf{0 , 0 1 0}$ \\
\hline $\begin{array}{l}\text { zachęcanie do zbadania } \\
\text { w sądzie biskupim } \\
\text { ważności naszego } \\
\text { małżeństwa } \\
\text { sakramentalnego }\end{array}$ & 1,75 & 1,63 & 2,63 & 1,53 & 2,58 & 1,41 & 0,88 & 6,531 & $\mathbf{0 , 0 3 8}$ \\
\hline $\begin{array}{l}\text { zrozumienie przez } \\
\text { duszpasterzy naszej } \\
\text { sytuacji oraz osobistych } \\
\text { racji i powodów życia } \\
\text { w nowym związku }\end{array}$ & 3,13 & 1,07 & 3,56 & 0,92 & 3,58 & 1,11 & 0,45 & 11,695 & 0,003 \\
\hline
\end{tabular}

*Oznaczenia: M - średnia, SD - odchylenie standardowe; dM - różnice między średnimi, H Wynik testu Kruskala-Wallisa, p - poziom istotności. Pogrubioną czcionką zaznaczono wyniki zawierające różnice istotne statystycznie. 
Zaprezentowane wyniki w tabeli 2 wskazują, że wraz ze wzrostem wieku respondentów częstsze jest ich oczekiwanie wobec towarzyszenia duszpasterskiego, poprzez tworzenie wspólnot dla par niesakramentalnych, gdzie mogliby dzielić się doświadczeniami ( $\mathrm{p}=0,001)$, zapraszanie ich do udziału we Mszy świętej $(\mathrm{p}<0,001)$, organizowanie rekolekcji dla par w sytuacjach nieuregulowanych $(\mathrm{p}<0,001)$, uwagę kapłanów i większe zainteresowanie ich sytuacją $(\mathrm{p}=0,002)$, zapraszanie na drogę rozeznawania ze spowiednikiem możliwości otrzymania rozgrzeszenia i przyjęcia Komunii świętej $(\mathrm{p}=0,005)$, pomoc duchową w przebaczaniu sobie i innym oraz naprawieniu krzywd $(\mathrm{p}=0,010)$, zachęcanie do zbadania w sądzie biskupim ważności ich małżeństwa sakramentalnego $(\mathrm{p}=0,038)$, a także poprzez zrozumienie przez duszpasterzy ich sytuacji oraz osobistych racji i powodów życia w nowym związku ( $\mathrm{p}=0,003)$.

$\mathrm{W}$ badaniach sprawdzono oddziaływanie zmiennej wykształcenia na odpowiedzi respondentów dotyczące oczekiwań względem duszpasterskiego towarzyszenia parom w sytuacjach nieuregulowanych. Porównania dokonano za pomocą testu Kruskala-Wallisa. Wyniki prezentuje tabela 3.

Tabela 3. Oczekiwania wobec towarzyszenia duszpasterskiego w sytuacjach nieuregulowanych a wykształcenie respondentów

\begin{tabular}{|c|c|c|c|c|c|c|c|c|c|}
\hline \multirow[t]{2}{*}{$\begin{array}{l}\text { Oczekiwania wobec } \\
\text { towarzyszenia } \\
\text { duszpasterskiego }\end{array}$} & \multicolumn{2}{|c|}{\begin{tabular}{|c|} 
podstawowe/ \\
zawodowe/ \\
średnie $(n=60)$
\end{tabular}} & \multicolumn{2}{|c|}{$\begin{array}{c}\text { wyższe } \\
\text { humanistyczne } \\
(\mathbf{n}=30)\end{array}$} & \multicolumn{2}{|c|}{$\begin{array}{c}\text { wyższe } \\
\text { techniczne/n. } \\
\text { ścisłych }(n=34)\end{array}$} & \multirow[t]{2}{*}{ dM } & \multirow[t]{2}{*}{$\mathbf{H}$} & \multirow[t]{2}{*}{$\mathbf{p}$} \\
\hline & $\mathbf{M}^{*}$ & SD & $\mathbf{M}$ & SD & $\mathbf{M}$ & SD & & & \\
\hline Wynik sumaryczny & 76,85 & 19,08 & 65,28 & 30,25 & 66,50 & 29,63 & 11,57 & 2,941 & 0,230 \\
\hline \multicolumn{10}{|l|}{ Pytania szczegółowe } \\
\hline $\begin{array}{l}\text { zachęcanie do zbadania } \\
\text { w sądzie biskupim wa- } \\
\text { żności naszego małżeń- } \\
\text { stwa sakramentalnego }\end{array}$ & 2,67 & 1,46 & 1,80 & 1,35 & 2,41 & 1,78 & 0,87 & 7,916 & 0,019 \\
\hline $\begin{array}{l}\text { pomoc w otwieraniu się } \\
\text { na miłość Boga do nas }\end{array}$ & 3,30 & 1,05 & 2,60 & 1,61 & 2,47 & 1,48 & 0,83 & 9,171 & $\mathbf{0 , 0 1 0}$ \\
\hline $\begin{array}{l}\text { organizowanie modlitw } \\
\text { o uzdrowienie zranień } \\
\text { w relacjach }\end{array}$ & 3,03 & 0,96 & 2,60 & 1,33 & 1,94 & 1,61 & 1,09 & 10,334 & 0,006 \\
\hline $\begin{array}{l}\text { pomoc w religijnym } \\
\text { wychowaniu dzieci }\end{array}$ & 2,87 & 1,21 & 2,00 & 1,44 & 2,47 & 1,44 & 0,87 & 7,609 & 0,022 \\
\hline
\end{tabular}

*M - średnia, SD - odchylenie standardowe; dM - różnice między średnimi, H - Wynik testu Kruskala-Wallisa, p - poziom istotności. Pogrubioną czcionką zaznaczono wyniki zawierające różnice istotne statystycznie. 
$\mathrm{Z}$ badań wynika, że respondenci z wykształceniem podstawowym, zawodowym i średnim częściej oczekują duszpasterskiego towarzyszenia, niż badani z wykształceniem wyższym humanistycznym oraz wyższym technicznym i w zakresie nauk ścisłych. Osoby słabiej wykształcone istotnie częściej oczekują towarzyszenia poprzez zachęcanie do zbadania w sądzie kościelnym ważności ich małżeństwa sakramentalnego $(\mathrm{p}=0,019)$, pomoc $\mathrm{w}$ otwieraniu się na miłość Boga do nich $(\mathrm{p}=0,010)$, organizowanie modlitw o uzdrowienie zranień $\mathrm{w}$ relacjach $(\mathrm{p}=0,006)$ oraz pomoc $\mathrm{w}$ religijnym wychowaniu dzieci $(\mathrm{p}=0,022)$.

W analizie wyników badań sprawdzono wpływ zmiennej stosunku do wiary na odpowiedzi respondentów dotyczące oczekiwań duszpasterskiego towarzyszenia. Porównania dokonano za pomocą testu Manna-Whitney'a. Wyniki zestawiono w tabeli 4 .

Tabela 4. Oczekiwania wobec towarzyszenia duszpasterskiego w sytuacjach nieuregulowanych a stosunek respondentów do wiary

\begin{tabular}{|c|c|c|c|c|c|c|c|}
\hline \multirow[t]{2}{*}{$\begin{array}{l}\text { Oczekiwania wobec towarzyszenia } \\
\text { duszpasterskiego }\end{array}$} & \multicolumn{2}{|c|}{$\begin{array}{l}\text { GWiP } \\
(n=66)\end{array}$} & \multicolumn{2}{|c|}{$\begin{array}{l}\text { SWiP } \\
(n=58)\end{array}$} & \multirow[t]{2}{*}{ dM } & \multirow[t]{2}{*}{$\mathbf{Z}$} & \multirow[t]{2}{*}{$\mathbf{p}$} \\
\hline & $\mathbf{M} *$ & SD & $\mathbf{M}$ & SD & & & \\
\hline Wynik sumaryczny & 83,00 & 13,11 & 57,81 & 29,60 & 25,19 & 4,949 & $<0,001$ \\
\hline \multicolumn{8}{|l|}{ Pytania szczegółowe } \\
\hline $\begin{array}{l}\text { Wyjaśnianie, w jaki sposób budować } \\
\text { więź duchową z Bogiem i partnerem }\end{array}$ & 3,52 & 0,71 & 2,21 & 1,39 & 1,31 & 5,419 & $<0,001$ \\
\hline $\begin{array}{l}\text { tworzenie wspólnot dla par } \\
\text { niesakramentalnych, gdzie moglibyśmy } \\
\text { dzielić się doświadczeniami }\end{array}$ & 3,45 & 0,96 & 2,07 & 1,59 & 1,39 & 5,087 & $<0,001$ \\
\hline $\begin{array}{l}\text { Zapraszanie nas do udziału we } \\
\text { Mszy świętej }\end{array}$ & 3,42 & 0,86 & 2,28 & 1,32 & 1,15 & 5,189 & $<0,001$ \\
\hline $\begin{array}{l}\text { organizowanie rekolekcji dla par } \\
\text { w sytuacjach nieuregulowanych }\end{array}$ & 3,55 & 0,79 & 2,38 & 1,48 & 1,17 & 4,862 & $<0,001$ \\
\hline $\begin{array}{l}\text { uwagę kapłanów i większe } \\
\text { zainteresowanie naszą sytuacją }\end{array}$ & 3,55 & 0,86 & 2,66 & 1,22 & 0,89 & 4,501 & $<0,001$ \\
\hline $\begin{array}{l}\text { pomoc w osobistej modlitwie } \\
\text { słowem Bożym }\end{array}$ & 3,27 & 0,87 & 1,97 & 1,46 & 1,31 & 5,136 & $<0,001$ \\
\hline $\begin{array}{l}\text { zapraszanie na drogę rozeznawania ze } \\
\text { spowiednikiem możliwości otrzymania } \\
\text { rozgrzeszenia i przyjęcia Komunii świętej }\end{array}$ & 3,55 & 1,11 & 2,83 & 1,40 & 0,72 & 3,711 & $<0,001$ \\
\hline $\begin{array}{l}\text { wyjaśnianie, co to jest komunia duchowa } \\
\text { i jak ją przyjmować }\end{array}$ & 3,42 & 0,90 & 1,93 & 1,42 & 1,49 & 5,918 & $<0,001$ \\
\hline
\end{tabular}




\begin{tabular}{|l|c|c|c|c|c|c|c|}
\hline $\begin{array}{l}\text { pomoc duchową w przebaczaniu sobie } \\
\text { i innym oraz naprawieniu krzywd }\end{array}$ & 3,27 & 0,97 & 2,62 & 1,51 & 0,65 & 2,165 & $\mathbf{0 , 0 3 0}$ \\
\hline $\begin{array}{l}\text { zapraszanie nas na adorację } \\
\text { Najświętszego Sakramentu }\end{array}$ & 3,36 & 0,82 & 1,97 & 1,31 & 1,40 & 5,809 & $<\mathbf{0 , 0 0 1}$ \\
\hline $\begin{array}{l}\text { zachęcanie do zbadania w sądzie } \\
\text { biskupim ważności naszego małżeństwa } \\
\text { sakramentalnego }\end{array}$ & 2,82 & 1,39 & 1,90 & 1,60 & 0,92 & 3,306 & $\mathbf{0 , 0 0 1}$ \\
\hline $\begin{array}{l}\text { pomoc w otwieraniu się na miłość Boga } \\
\text { do nas }\end{array}$ & 3,36 & 0,89 & 2,38 & 1,62 & 0,98 & 3,108 & $\mathbf{0 , 0 0 2}$ \\
\hline $\begin{array}{l}\text { wsparcie w kryzysie z powodu poczucia } \\
\text { wykluczenia z Kościoła }\end{array}$ & 3,09 & 1,25 & 2,31 & 1,57 & 0,78 & 2,719 & $\mathbf{0 , 0 0 7}$ \\
\hline $\begin{array}{l}\text { zrozumienie przez duszpasterzy naszej } \\
\text { sytuacji oraz osobistych racji i powodów } \\
\text { życia w nowym związku }\end{array}$ & 3,79 & 0,60 & 3,07 & 1,27 & 0,72 & 4,150 & $<\mathbf{0 , 0 0 1}$ \\
\hline $\begin{array}{l}\text { zapraszanie nas do czynienia możliwego } \\
\text { dobra w aktualnej sytuacji, w jakiej się } \\
\text { znajdujemy }\end{array}$ & 3,55 & 0,66 & 2,38 & 1,55 & 1,17 & 4,232 & $<\mathbf{0 , 0 0 1}$ \\
\hline $\begin{array}{l}\text { organizowanie modlitw o uzdrowienie } \\
\text { zranień w relacjach }\end{array}$ & 3,00 & 0,99 & 2,21 & 1,53 & 0,79 & 2,819 & $\mathbf{0 , 0 0 5}$ \\
\hline $\begin{array}{l}\text { stwarzanie okazji do włączenia się } \\
\text { w życie parafii }\end{array}$ & 3,00 & 1,11 & 2,21 & 1,48 & 0,79 & 2,993 & $\mathbf{0 , 0 0 3}$ \\
\hline
\end{tabular}

*Oznaczenia: M - średnia, SD - odchylenie standardowe; dM - różnice między średnimi, Z - Wynik testu Manna-Whitney'a, p - poziom istotności. GWiP - głęboko wierzący i praktykujący; SWiP - słabo wierzący i praktykujący. Pogrubioną czcionką zaznaczono wyniki zawierające różnice istotne statystycznie.

Wyniki zaprezentowane w tabeli 4 wskazują, że osoby głęboko wierzące i praktykujące częściej niż osoby słabo wierzące i praktykujące oczekują prawie wszystkich form duszpasterskiego towarzyszenia parom w sytuacjach nieuregulowanych.

\section{WNIOSKI PASTORALNE}

Przedstawione wyżej wyniki badań pozwalają sformułować kilka wniosków pastoralnych dla duszpasterskiego towarzyszenia osobom żyjącym w sytuacjach nieuregulowanych. Ponad połowa ankietowanych oczekuje od duszpasterzy zachęty i wsparcia do zbadania w sądzie kościelnym ważności małżeństwa sakramentalnego. Ze względu na nierzadkie dzisiaj występowanie niektórych przyczyn nieważności małżeństwa, pomoc w rozpoznaniu możliwości złożenia skargi na nieważność małżeństwa sakramentalnego powinno być jednym z pierwszych kroków duszpasterskiego towarzyszenia tym osobom. 
Trzy czwarte katolików rozwiedzionych, żyjących w nowych związkach, zdecydowanie lub w dużym stopniu oczekuje od duszpasterskiego towarzyszenia przede wszystkim zrozumienia ich sytuacji, osobistych racji oraz powodów życia w nowym związku, a także liczy na zaproszenie ich na drogę rozeznawania ze spowiednikiem możliwości otrzymania rozgrzeszenia i przyjęcia Komunii świętej. Odpowiedzią może być możliwość szczerej rozmowy z kapłanem w formie kierownictwa duchowego, co pozwoliłoby im stopniowo dorastać do wymagań prawdy Ewangelii i coraz głębiej włączać się w życie wspólnoty Kościoła.

Badania wskazują także na ważność organizowania rekolekcji dla par w sytuacjach nieuregulowanych, potrzebę pomocy w otwieraniu się na miłość Boga oraz pomocy duchowej w przebaczaniu sobie i innym, a także w naprawieniu krzywd.

Adekwatną odpowiedzią mogłoby być organizowanie rekolekcji ewangelizacyjnych oraz warsztatów dialogu i komunikacji w parze, co służyłoby umacnianiu wiary i wzajemnej miłości, a pośrednio zapobiegałoby także kryzysom małżeńskim. Tymi formami częściej mogą być zainteresowane osoby głęboko wierzące i praktykujące. Z badań wynika także, iż ze wzrostem wieku respondentów wzmaga się ich potrzeba zrzeszania się we wspólnotach dla par niesakramentalnych. Stwarzałoby to możliwość pomocy w budowaniu więzi z Bogiem i partnerem, słuchaniu słowa Bożego, formacji i coraz głębszego rozeznawania działania Boga w ich życiu. Ponadto, regularna możliwość rozmowy z kompetentnym duszpasterzem, prowadzącym taką wspólnotę, byłaby odpowiedzią na oczekiwania osób w sytuacjach nieuregulowanych. Rozmowy te mogą pomagać w pogłębianiu życia modlitwy, odkrywaniu Bożej pedagogii łaski w ich życiu, a także w dążeniu do osiągnięcia pełni planu Bożego i coraz pełniejszego włączenia we wspólnotę Kościoła.

Wyniki badań wskazują również na potrzebę zapraszania przez duszpasterzy osób i par w nieuregulowanych sytuacjach małżeńskich do czynienia możliwego dobra w ich aktualnej sytuacji. Te oczekiwania powinny znaleźć swe spełnienie na poziomie duszpasterstwa parafialnego poprzez osobiste nawiązanie kontaktu przez kapłana z tymi parami, delikatne i pełne szacunku traktowanie oraz stopniowe włączanie w życie parafii. Takie doświadczenie mogłoby przywracać parom nadzieję, budzić w nich coraz większe zaufanie i otwartość wobec Kościoła, który ze swej istoty powinien towarzyszyć w drodze do uzdrowienia i zbawienia. Najważniejsze wydaje się to, aby duszpasterstwo nie pomijało tych wiernych, a co gorsza nie dystansowało się od nich, ale przyjmowało ich i włączało, udostępniając stosowne środki zbawienia. 


\section{BIBLIOGRAFIA}

Benedykt XVI. Posynodalna adhortacja apostolska „Sacramentum caritatis”. Dostęp 28.12.2020. http://www.vatican.va/content/benedict-xvi/pl/apost_exhortations/documents/hf_ben-xvi_exh _20070222_sacramentum-caritatis.html.

Franciszek. List apostolski „Patris corde”. Dostęp 20.12.2020. http://www.vatican.va/content /francesco/pl/apost_letters/documents/papa-francesco-lettera-ap_20201208_patris-corde.html.

Franciszek. Adhortacja apostolska „Evangelii gaudium”. Kraków: Wydawnictwo M, 2013.

Franciszek. Rodzina uratuje świat. Gliwice: Fundacja Instytut Globalizacji, 2016.

Franciszek. Posynodalna adhortacja apostolska „Amoris laetitia”. Kraków: Wydawnictwo M, 2016.

Goleń, Jacek „Miłość małżeńska w świetle badań narzeczonych.” Studia nad Rodzina 18(2014), 2, 35: 107-132.

Goleń, Jacek „The Challenges of Accompanying the Family in Light of the Apostolic Exhortation Amoris Laetitia.” Rocznik Teologii Katolickiej 17(2018): 103-117.

Goleń, Jacek „The Renewal of Pastoral Care of the Family in the Light of the Apostolic Exhortation Amoris Laetitia." Roczniki Teologiczne 64(2017), 6: 95-114.

Goleń, Jacek. „Pastoral Accompaniment for People in Irregular Situations.” W Catholic Family Ministry. The Scientific Reflection and the Practical Ministry of the Church, red. Jacek Golen, Ryszard Kamiński, Grzegorz Pyźlak, 103-117. Lublin: Wydawnictwo KUL, 2018.

Goleń, Jacek. „Towarzyszenie, rozeznawanie i integracja osób w nieuregulowanych sytuacjach małżeńskich.” W Konrad Glombik, Jacek Goleń, Antoni Nadbrzeżny. Droga miłosierdzia i integracji $w$ adhortacji 'Amoris laetitia'. Perspektywa dogmatyczna, moralna i pastoralna, 113-164. Lublin: Towarzystwo Naukowe KUL, 2020.

Kmiecik, Barbara. „Towarzyszenie duchowe małżonkom i osobom w sytuacjach nieregularnych w świetle adhortacji 'Amoris laetitia'”. Family Forum (2017): 107-124. Dostęp 23.12.202; DOI: $10.25167 / \mathrm{FF} / 2017 / 107-124$ 118-119.

Kucharčík, Richard. „Dowartościowanie świadectwa i towarzyszenia małżonków.” W Towarzyszyć matżeństwu i rodzinie. Inspiracje adhortacji apostolskiej 'Amoris laetitia' dla duszpasterstwa rodzin, red. Jacek Goleń, 213-223. Lublin: Wydawnictwo KUL, 2017.

Michasiów, Marian. „Osoby rozwiedzione żyjące w nowych związkach w realiach polskiego Kościoła. Spostrzeżenia zainspirowane przedsynodalnym kwestionariuszem”. Teologia i Moralność (2014), 1, 15: 131-147. Dostęp 2.12.2020; DOI: 10.14746/TIM.2014.15.1.9.

Nadbrzeżny, Antoni. „Sens i wartość sakramentu małżeństwa według adhortacji “Amoris laetitia””. W Konrad Glombik, Jacek Goleń, Antonii Nadbrzeżny. Droga miłosierdzia i integracji $w$ adhortacji 'Amoris laetitia'. Perspektywa dogmatyczna, moralna i pastoralna, 27-66. Lublin: Towarzystwo Naukowe KUL, 2020.

Papieska Komisja Biblijna. Czym jest człowiek? Zarys antropologii biblijnej. Kielce: Jedność, 2019.

Zinga, Nestor Basunga Kiama. „Teologiczne punkty węzłowe małżeństwa chrześcijańskiego”. W 'Amoris laetitia' jako ewangelia miłości i droga do przebycia, red. Giovanni del Missier, Antonio Gerardo Fidalgo, 85-102. Kraków: Wydawnictwo Homo Dei, 2019. 


\section{OCZEKIWANIA KATOLIKÓW ROZWIEDZIONYCH \\ ŻYJĄCYCH W NOWYCH ZWIAZZKACH \\ WOBEC DUSZPASTERSKIEGO TOWARZYSZENIA}

\section{Streszczenie}

Towarzyszenie pastoralne powinno być inspirowane miłością Boga. Obecnie odgrywa ono szczególnie ważną rolę w posłudze małżonkom w sytuacjach nieregularnych. Artykuł prezentuje oczekiwania katolików rozwiedzionych, żyjących w nowych związkach, wobec duszpasterskiego towarzyszenia w oparciu o badania empiryczne przeprowadzone na terenie Polski. Zawiera także wnioski pastoralne. Respondenci oczekują od duszpasterskiego towarzyszenia zrozumienia ich sytuacji, osobistych racji oraz powodów życia w nowym związku, rozeznawania możliwości otrzymania rozgrzeszenia i przyjęcia Komunii świętej, organizowania rekolekcji, pomocy w otwieraniu się na miłość Boga, wsparcia na drodze przebaczania sobie i innym oraz naprawienia wyrządzonych krzywd. Odpowiedzią na te oczekiwania powinno być przede wszystkim duszpasterstwo parafialne, które umożliwia osobisty kontakt kapłana z tymi osobami, delikatne i pełne szacunku traktowanie oraz stopniowe włączanie w życie parafii. Takie podejście może budzić nadzieję, zaufanie i otwartość wobec Kościoła. Przyjęcie, towarzyszenie i rozeznawanie duchowe z tymi osobami umożliwia ich stopniowe włączanie we wspólnotę Kościoła.

Słowa kluczowe: duszpasterskie towarzyszenie; rozeznawanie; katolicy rozwiedzeni; sytuacje nieregularne. 